\title{
Performance of Compost from Waterthyme (Hydrilla verticillata) in Bok Choy Growth (Brassica chinensis)
}

\author{
Raudatul Dahliana Safitri ${ }^{1}$, Yuspihana Fitrial ${ }^{2}$, Fatmawati², Agung Nugroho ${ }^{3 *}$ \\ ${ }^{1}$ Department of Natural Resources and Environmental Management, Post Graduate Program, LambungMangkurat University, Indonesia \\ ${ }^{2}$ Faculty of Fisheries, LambungM angkurat University, Indonesia \\ ${ }^{3}$ Department of Agro-industrial Technology, Faculty of Agriculture, LambungMangkurat University, Indonesia \\ *Email: anugroho@ulm.ac.id
}

\begin{abstract}
Waterthyme (Hydrilla verticillata) has a rapid growth rate in freshwater, especially rivers and irrigation channels, hence it becomes a disturbing factor and needs periodic cleaning.Dry H. verticillata contains nitrogen of $3.29 \%$, phosphorus of $0.52 \%$, and potassium of $6.34 \%$.The utilization of $H$. verticillata as compost has great potential, but there has not been found intensive research on the subject. This study aimed to examine the ability of $H$. verticillata as an alternative raw material for compost fertilizer in the bok choygrowth.This study used a Randomized Complete Block design (RCB) with a single factor by analyzing the data using ANOVA and continued with further tests using Least Significant Different (LSD).PO (control) was $100 \%$ soil, P1100\% cow manure, P2 100\% waterthyme, and P3 50\% waterthyme + 50\% cow manure.Bok Choy have optimal growth (88 g plant mass, $5 \mathrm{~g}$ root mass) in compost applications with a composition of $100 \%$ waterthyme ( $H$. verticillata) with a moisture content of $21.24 \%, \mathrm{pH} 8.50, \mathrm{C} 9.09 \%, \mathrm{C} / \mathrm{N}$ ratio 4.07, $\mathrm{N} 2.25 \%, P$ $1.38 \%, \mathrm{~K} 1.38 \%$, and organic matter $15.67 \%$.
\end{abstract}

Keywords-Hydrilla verticillata, compost, bok choy, alternative material.

\section{INTRODUCTION}

Bok choy vegetables are popular among Indonesian, consumed by all people from the lower to the upper class. Bok choy can grow well both in the lowlands and highlands. It has high economic value after cabbage, cauliflower, and broccoli. Bok choy is estimated to come from China and has been cultivated since 2500 years ago, then spread widely to the Philippines and Taiwan[1].

Its growth is affected by the type of fertilizer used. Farmers usually use chemical fertilizers to get maximum growth and yield but ignore the side effects [2]. Therefore, to replace this habit, pne alternative solution is by utilizing organic fertilizer from Hydrilla verticillata water thyme.

The Riam Kanan Reservoir is utilized by the government and the local community for a water reservoir, power plants, aquaculture, agriculture, mining, transportation, and others.The utilization of the Riam river might brings negative impact on water quality [2].The high pollutant load discharged by the community causes a surge in thegrowthof $H$. verticillata. Nitrogen, Phosphate, $\mathrm{pH}$, metals, and sunlight can accelerate the growth of waterthyme [2].H.verticillata can grow at high densities (more than 10 tons of dry weight per hectare - 1 year - 1, or more); and can block and damage natural wetlands [3].

H.verticillata has a moisture content of $90.42 \%$ (wb) [4] with the organic carbon content of $14.47 \%$ (wb) [5], and the nitrogen content of $45 \%$ (wb), so it has the potential to be used as compost fertilizer.

Compost is one of the organic fertilizers used in agriculture to reduce the application of inorganic fertilizers.Compost can improve the physical properties and microbiology of the soil [2].Composting is the process of converting biodegradable residues into hygienic and stable products. Compost from $H$. verticillate contaminated with heavy metals can be applied to plants. The remains pollutants such as heavy metal that is harmful to the environment and other elements will be transformed into less harmful substance[6].

The utilization of organic materials is currently considered the best effort in improving the productivity of marginal soils, including acid soils.Compost contains nutrients such as nitrogen and phosphate in the form of argon, protein, and humus complexes, whichare very difficult to absorb by plants [7].Some ways that have been done to improve nutrient status in compost are such as 
adding natural ingredients of bone flour, dried blood flour, banana bark, and biofertilizer [2].Em4 was discovered by Higa and James in 1997.Fermentation of organic substance by effective microorganisms (EM) produces lactic acid and amino acids, which can be absorbed directly by plants as antibiotics that can suppress the growth of harmful microorganisms.

\section{RESEARCH METHOD}

The materials used in this study were Hydrilla verticillata, cow manure, tub soil, palm sugar, EM4 activator liquid, and Bok choy seeds (Brassica oleracea). The tools used were large plastic bags (trash bag), tarps, weight balance, stationery, plastic clips, gloves, scissors, stirrers, buckets, measuring cups, label papers, and $\mathrm{pH}$ meter.

The research design used a Randomized Complete Block design (RCB) consisting of 6 treatments. Treatments are presented in Table 1.BasedonTable 1, eachtreatmentconsis tedofthreereplicationshencethere were 18 treatment units. Data from observations on various treatments were analyzed using theANOVA test with the help of SPSS 19 with a significance level $(\alpha)<0.05$.If there is a difference (significant effect), then it will be followed by the Least Significant Difference Test (LSD), but if there is no difference (no significant effect), further analysis is not needed.

Table 1. Formulationofcompostfertilizertreatment

\begin{tabular}{cl}
\hline Treatment & \multicolumn{1}{c}{ Concentration Comparison } \\
\hline Po & $100 \%$ soil \\
P1 & $100 \%$ cow manure \\
P2 & $100 \%$ H. verticillata \\
P3 & $50 \%$ H. verticillata $+50 \%$ cow manure \\
\hline
\end{tabular}

\section{Research Implementation Composting processing}

Compost production was based on a predetermined concentration.Rice bran and Em4 solution as a starter were added to ingredients that have been mixed with certain concentrations before and then fermented for 14 days.During the fermentation, compost was reversed.To maintain the temperature in the range of $40-50^{\circ} \mathrm{C}$, the fermenter should always be opened and reversed, after the temperature drops, the fermenter is closed again.

Compost that has been fermented for 14 days and mature compost has the criteria of being odorless anddark in color [8]. The compost was then tested for Nitrogen (N), Phosphorus (P), and Potassium (K) content.The mature compost was then applied as a growing medium for Bok choy plants.

\section{Soil Processing}

The soils used came from the Practice Land. The soil was then separated from the attach leaf trash or dirt

Seed Nursery

The nursery media consisted of a mixture of soil and cow manure with a ratio of 2:1.The seeds were spread evenly and then covered with soil thinly and watered.At the age of \pm 14 days, the seeds were transferred into the polybag.

\section{Preparation of Planting Medium}

Preparation of planting media using three replications, five treatments, and one control. Each combination with a different type of treatment was put into a $5 \mathrm{~kg}$ polybag, size $35 \mathrm{~cm} \times 35 \mathrm{~cm}$, with a certain concentration of cow manure, waterthyme compost, and soil with a ratio of $1: 2: 1$.

\section{Planting and Maintenance}

The seeds of cauliflower and lettuce were grown for \pm 14 days before being transferred to a polybag that had been filled with cow manure, compost, and soil that has been left for one night. Polybags containing soil media, cow manure, and compost were given holes with the same depth, and each hole was filled with bok choy seeds and watered.Maintenance was done twice a day at morning and evening. Maintenance includes watering and cleaning weeds.

\section{Data Collection}

Data collection was done once a week. The changes observed were as follows:

\section{Plant Height}

Plant height was measured from the surface of the planting medium to the growth point, measured using a ruler.

\section{Leaf Counting}

Leaves counting was carried out during the growth period and calculated once a week during the planting period. The calculated leaves were those that have opened perfectly, consisting of stems and leaves.

\section{Leaf Width}

Leaf width was measured during the growth period and was carried out once a week during the planting period by using a ruler from the surface of the planting medium tothegrowingpoint.

\section{Weight of plant canopy and fibrous roots}

Measurements were conducted after the harvest period. The plant canopy and fibrous roots were weighed using a digital analytical balance. 


\section{RESULTS AND DISCUSSIONS \\ Chemical Composition of Compost Fertilizer}

The observation showed that waterthyme compost (Hydrilla verticillata) contained Nitrogen $(\mathrm{N})$, Phosphorus ( $\mathrm{P})$, and Potassium (K).The compos tanalysis based on several treatments I spresented in Table2.

Table. 2. Analysis of compost fertilizers based on SNI 2004

\begin{tabular}{|c|c|c|c|c|c|c|c|}
\hline \multirow{2}{*}{ No } & \multirow{2}{*}{ Examination } & \multirow{2}{*}{ Unit } & \multicolumn{4}{|c|}{ Average Treatment } & \multirow{2}{*}{$\begin{array}{c}\text { SNI } \\
2004\end{array}$} \\
\hline & & & Po & P1 & P2 & P3 & \\
\hline 1 & $\mathrm{~N}$ & $\%$ & 0.29 & 2.23 & 2.25 & 0.99 & 0.4 \\
\hline 2 & $P$ & $\%$ & 0.02 & 0.39 & 0.56 & 0.53 & 0.1 \\
\hline 3 & K & $\%$ & 0.04 & 0.63 & 1.38 & 0.32 & 0.2 \\
\hline 4 & $\mathrm{pH}$ & & 7.46 & 8.15 & 8.5 & 7.95 & $\begin{array}{l}6.80 \\
7.49\end{array}$ \\
\hline
\end{tabular}

Basedon Table2, it is identified that several parameters are in accordance with SNI 2004 quality standards.These parameters are used to determine the quality of H.verticillata compost.Compost application can improve soil physical properties and microbiology[8].Nutrient content in compost such as nitrogen and phosphate is in the form of complex compounds of argon, protein, and humic, which are very difficult to absorb by plants [7].Nitrogen $(\mathrm{N})$ from NPK is required by plants for the growth of shoots, stems, and leaves.Phosphorus $(\mathrm{P})$ functions in stimulating the growth of roots, fruits, seeds, while Potassium $(\mathrm{K})$ to increase plant resistance to pests and diseases [9]. A good $\mathrm{pH}$ range for plants based on SNI-2004 is between 6.80-7.49, while based on the Department of Agriculture 2011 is between 4-9. In that range, plants can grow optimally.

\section{Number of the Leaf}

Leaves are the place where photosynthesis takes place, which is to convert sunlight energy into a foodproducing source used in the growth, development, and production of harvesting materials [10].

Statistical analysis showed that all treatments have no significant effect on the number of leaves $(\alpha$ $<0.05$ ) with a significance value on the First Week (W1) of 0.926 , W2 of $0.891, \mathrm{~W} 3$ of 0.968 , and M4 of 0.631.It is presumed that the concentration of compost fertilizer did not affect the number of leaf plants based on the ANOVA test, but it affected the number of nutrients contained in it.[11].

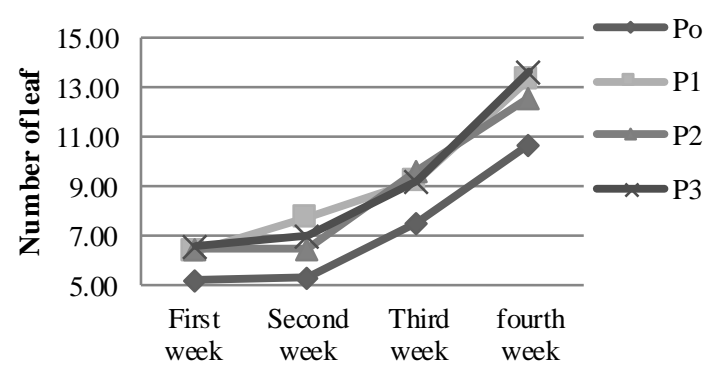

Fig.1: Number of the leaf.

The RiamKanan Reservoir is utilized by the government and the local community for a water reservoir, power plants, aquaculture, agriculture, mining, transportation, and others. The utilization of the Riam river might brings negative impact on water quality [2].The high pollutant load discharged by the community causes a surge in thegrowthofH.verticillata. Nitrogen, Phosphate, $\mathrm{pH}$, metals, and sunlight can accelerate the growth of waterthyme [2].H.verticillata can grow at high densities (more than 10 tons of dry weight per hectare - 1 year - 1, or more); and can block and damage natural wetlands [3].

The highest P2 valuewas 14.08 in thefourthweek (W4), andthelowestvalue Po was 10.67 (Figure 1). 100\% of $H$. Verticillata compost produces the highest value compared to $100 \%$ soil(Po).It is possible because $\mathrm{P} 2$ has a higher $\mathrm{N}$ content $(2.25 \%)$ than the research conducted by Marwan et al. [13] (1.37\%). The content of $\mathrm{N}$ in Po was only $0.29 \%$. This is what causes the difference in the number of leaves in Bok choy.

\section{Diameter of the Leaf}

Leaf diameter is a determinant in the absorption of sunlight so that the photosynthetic rate is determined based on leaf diameter.The wider the diameter of the leaves, the more sunlight will be absorbed so that the rate of photosynthesis is also higher.On the contrary, the smaller the diameter, the less amount of sunlight absorbed in photosynthesis [10].

ANOVA statistical analysis showed that all treatments have a significant effect on leaf diameter $(\alpha$ $<0.05$ ) with a significance value on the First Week (W1) of 0.017 , W2 of $0.014, \mathrm{~W} 3$ of 0.022 , and W4 of 0.017 .It may be caused by a varied amount of $\mathrm{N}$ element uptake in each treatment [12].

The BNT further test (p-value <0.05) showed that the leaf diameter with the treatment of $100 \%$ soil concentration was 5.28. This treatment was significantly different from the treatment of $100 \%$ waterthyme compost, namely 7.26.Increased in diameter indicates that the sunlight absorption rate is increasing so that the photosynthesis process continues rapidly [10]. 


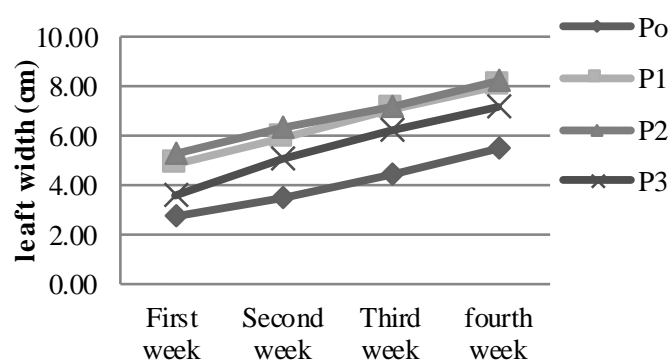

Fig.2. Leafdiameterofbok choy.

Figure 2 shows an increase in the diameter of Bok choy leaves from the first week (W1) to the seventh week (W7).It is estimated that Bok choy has adapted since the planting period.The analysis showed that $\mathrm{N}$ content in H.verticillata waterthyme compost was $1.74 \%$.Other researchers found that the $\mathrm{N}$ level in H.verticillata waterthyme was $1.37 \%$ [13], while in cow manure was $0.41 \%$ [6].

The highest value in $\mathrm{P} 2(8.21 \mathrm{~cm})$ was obtained in the fourth week (W4), and the lowest value of Po was $5.52 \mathrm{~cm} . \mathrm{P} 2$ with the application of $100 \% \mathrm{H}$. verticillata waterthyme compost has the highest value compared to Po $100 \%$ soil.It is in line with the content of $\mathrm{N}$ in $\mathrm{P} 2$ of $2.25 \%$ and Po of $0.29 \% . N$ element will affect leaf diameter, stem growth, number of leaves, roots, and others [14]. The variation in the average leaf diameter is due to the comparison between different treatments and the number of $\mathrm{N}$ elements in compost.

\section{Weight of the Plant}

Plants that absorb optimal macro and micronutrients will promote optimal growth.In addition, the high availability of nutrients will increase the growth of vegetative organs, so that plant growth becomes optimal, whereas low nutrients will result in non-optimal growth[5].

ANOVA statistical analysis showed that all treatments had no significant effect on plant fresh weight $(\alpha<0.05)$ with a significant value of 0.100 .It is possibly due to the comparison of the concentration between treatments based on nutrients found in the growing media.Availability of $\mathrm{N}$ elements will affect plant weights [14].

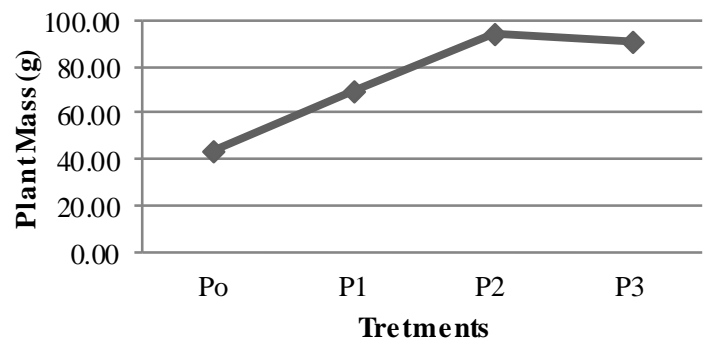

Fig.3: Weight of bokchoy.
Figure 3 shows that Po has the lowest weight value of 25.67 grams, while the highest value is in P2 of 93.75 grams.Po with $100 \%$ soil concentration produces the lowest value. This is presumably due to the availability of balanced or unbalanced macro and micronutrients, and NPK content.Nutrients availability is very needed in plant growth.NPK nutrients will increase Bok choy weight, and it indicates optimal growth [15].

\section{Weight of the Roots}

The fresh weight of roots determines plant growth based on the amount of nutrient uptake and will affect the development of plants based on the photosynthetic on leaves [16]. ANOVA statistical analysis showed that all treatments did not significantly affect the fresh weight of plant roots $(\alpha<0.05)$ with a significant value of 0.255 .It is likely due to the identical amount of macro, micro, and water uptake, so that root growth becomes uniform.In addition, the treatment concentration did not affect the amount of $\mathrm{K}$ nutrient prepared in the media [1].

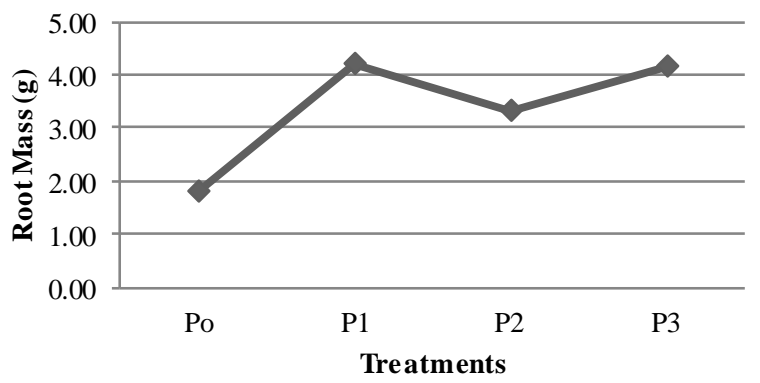

Fig.4: Weight of bokchoy's roots.

Figure 4 shows that the application of $25 \%$ cow manure produces a root weight of 4.20 grams.It is higher compared to the application of $100 \%$ soil, which is only 1.82 gram. Variations in plant weights are caused by variations in the type of planting media.The lowest value is considered to occur because of the nature of the soil, which cannot bind water [1]. The high value is caused by the availability of nutrients and sufficient water so that the growth and rooting weight are good.Availability of NPK nutrients will increase the weight of Bok choyroots [15].

\section{CONCLUSION}

The NPK content in P1, P2, and P3, is in accordance with SNI 2004 except for Po. The best treatment is obtained from the application of $100 \%$ compost from $H$. verticillata waterthyme. The parameters produced are higher than the application of cow manure or soil. 


\section{REFERENCES}

[1] Priadi, D. (2017). Utilization of woody leaves as organic fertilizer for vegetable crops and corn. 71-78.

[2] Brahmana, S. S., Achmad, F. (2012). The potential pollutant of Nitrogen, Phosphate, Water Quality, Trophic Status, and Stratification of the Riam Kanan Dam.Jurnal Sumber Daya Air, 8(1), 53-66.

[3] Barokah, R. (2017). L .) Effect of the Application of Different Types of Manure.Jurnal Agro Complex 1(3):120-125.

[4] Widarti, Budi Nining, Wardhini, Wardah Kusuma, and Sarwono, E. (2015). The Effect of C/N Ratio of Raw Materials on compost Production from Cabbage and Skin of Kelua Samarinda Banana. 1 Program. Jurnal Integrasi Proses, 5(2), 75-80.

[5] Elpawati, E., Dara, S. D., and Dasumiati, D. (2016). Optimizing the Compost Fertilizers application with the Addition of Effective Microorganism 10 (Em10) to the Productivity of Corn (Zea mays L.) Plants. $A L$ Kauniyah: Jurnal Biologi, 8(2), 77-87. https://doi.org/10.15408/kauniy ah.v8i2.2693

[6] Jain, M. S., and Kalamdhad, A. S. (2018). Efficacy of batch mode rotary drum composter for management of aquatic weed (Hydrilla verticillata (L.f.) Royle). Journal of Environmental Management, 221(May), 20-27. https://doi.org/10.1016/j.jenvman.2018.05.055

[7] Jain, M. S., and Kalamdhad, A. S. (2019). Drum composting of nitrogen-rich Hydrilla verticillata with carbon-rich agents: Effects on composting physics and kinetics. Journal of Environmental Management, 231(October 2018), 770-779. https://doi.org/10.1016/j.jenvman.2018.10.111

[8] Novi Rahmawanti and Novrian Dony. (2014). Production of Organic Fertilizers from Household Organic Waste by Adding EM4 Activators in Kayu Tangi Area,Ziraa'ah, 39, 1-7.

[9] Nuryadin, I., Nugraha, D. R., and Sumekar, Y. (2016). Growth and yield of cauliflower on the combination of inorganic fertilizers and organic fertilizers (Brassica oleracea var. Botrytis L.). Jurnal Ilmu Pertanian Dan Peternakan, 4(2), 259-268. https://doi.org/10.1016/S0022-5193(03)00028-6

[10] Nursayuti. (2017). Response to Soybean Plant Growth and Production Due to the Level of Soil Processing and Weed Control Techniques. Jurnal S. Pertanian 1 (1) : 20 $-27$.

[11] Munthe, K., Pane, E., and Panggabean, E. L. (2018). Cultivation of Black Mustard Plant (Brassica juncea L.) in Vertically Cultivated Different Planting Media. Agrotekma: Jurnal Agroteknologi Dan Ilmu Pertanian, 2(2), 138.

https://doi.org/10.31289/agr.v2i2.1632

[12] Astria, P., and Suntari, R. (2017). Application of Urea and Compost of Cocoa pod to Increase Availability and Uptake of N, P, K and Production of Bok choy in Inceptisol soil in Tulungrejo, Batu.Jurnal Tanah dan Sumberdaya Lahan Vol 4 No 1 : 453-461.
[13] Marwan, Haruna, N., and Yasin, S. M. (2017).Utilization of Hydrilla verticillata (L.F.) Royle as Green Fertilizer for Cocoa Seedlings Growth (Theobroma Cacao L.). Journal TABARO, 1(1), 1-10.

[14] Moi, A. R., Pandiangan, D., Siahaan, P., and Agustina, M. (2015). Examination of the application of Liquid Organic Fertilizer from Water Hyacinth (Eichhornia crassipes) on Black Mustard Growth (Brassica juncea), Jurnal Mipa Unsrat Online 4 (1) 15-19

[15] Arinong, A. R., Rukka, H., and Vibriana, L. (2008). Bokashi adduction. Growth and Production of Bok choy with Bokashi Adduction, Jurnal Agrisistem, 4(2).

[16] Purnama, rizki haqa, Santoso, sartono joko, and Hardiatmi, S. (2013). Effect of water hyacinth comp ost dose and spacing on growth and yield of black mustard. Jurnal Inovasi Pertanian, 12(2), 95-107.

[17] Marliah, A., Nurhayati, and Riana, R. (2013). Effect of Varieties and Concentrations of Compound Fertilizers on Growth and Yield of Cabbage (Brassica oleracea L.). Jurnal Floratek, 8(2), 118-126.

[18] Singh, J., and Kalamdhad, A. S. (2011). Effects of Heavy Metals on Soil, Plants, Human Health and Aquatic Life Making bricks using variety of solid waste View project Anaerobic digestion View project. (September 2014). Retrieved from www.ijrce.org

[19] Trivana, L., and Pradhana, A. Y. (2017). Optimization of composting time and goat manure quality and coconut coir dust with PROMI bio-activators and Orgadec. Jurnal Sain Veteriner, 35(1), 136. https://doi.org/10.22146/jsv.29301

[20] Sargiman, G., Wiliana, T., and Panjaitan, S. (2013). Gatot Sargiman \& Tiurma Wiliana Susanti Panjaitan. Jurnal Agroknow, 1(1), 7-12. 